\title{
Corruption in Lebanon: An Exploratory Study About Lebanese Managers' and Employees' Perceptions
}

\author{
Chirine Khalil Nassar ${ }^{1} \&$ Hussin Jose Hejase ${ }^{2}$ \\ 1 Ph.D. Candidate, Faculty of Business Administration, the Bucharest University of Economic Studies, \\ Bucharest, Romania \\ ${ }^{2}$ IEEE Senior Member, Professor and Senior Researcher, Beirut, Lebanon \\ Correspondence: Hussin J. Hejase, Senior Researcher, Prof. Business Administration, Beirut, Lebanon. E-mail: \\ hhejase@gmail.com
}

Received: June 20, 2021

Accepted: July 6, 2021

Online Published: July 15, 2021

doi:10.20849/abr.v6i1.912

URL: https://doi.org/10.20849/abr.v6i1.912

\begin{abstract}
Corruption is one of the major factors which affects the development of the economic sector in Lebanon. The purpose of the present study was to investigate the ways in which the perceptions on corruption differed among managers and employees in Lebanese businesses. The study focused on the underlying assumptions made about corruption, the ways in which corruption affects business operations, and the preference for certain strategies to deal with corruption in the business sector. The study followed a quantitative approach relying on a web-based survey. The final valid sample consisted of 50 Lebanese managers and employees. The results showed a positive inclination toward the corrupt behaviour either due to social norms which tolerate corruption or as a result of high-performance expectations from superiors. In addition, findings showed large discrepancies in regard to the contribution of organizational norms to the proliferation of corruption in the business sector. In fact employees considered that managers often overlook and sometimes even encourage corrupt behaviours that allow the attainment of organizational goals. The study highlights that corruption is engrained in Lebanon and has become prevalent to high extent that business actors use corrupt practices to be able to perform their activities and maintain their competitiveness. The findings of the study stress the urgency for business practitioners to take immediate action to mitigate corrupted actions by introducing changes in the organizational culture. Stressing and encouraging ethical values to combat corruption is a priority for all business actors as well as for public policy makers. Mediation of corruption necessitates more public awareness campaigns disclosing the negative effects of corruption on the health of sound business and the economy of the country at large.
\end{abstract}

Keywords: corruption, business sector, organizational norms, motivation, costs, Lebanon

\section{Introduction and Background}

Maxwell et al. (2008) assert that "corruption is about the abuse of power for private gain. Although this is as financial power; bribes, kickbacks, falsified expense reports and the like other forms. The abuse of powerful positions to get jobs for family and friends, the abuse of entrusted power in the allocation of aid or in the demand for sexual favors or subservience in return for aid. All of this is corruption" (p. 8). Corruption is known to affect the social and economic development of countries, playing a major role in maintenance of ineffective economic and political systems (Wei, 1998; Ahmad et al., 2012; Šumah, 2018). However, although corruption is present in all countries, its negative effects are most visible in the case of countries that have an underdeveloped public infrastructure and weak democratic systems which are unable to protect the interests of the citizens from the whims of the ruling class (Svensson, 2005). Judge, McNatt \& Xu (2011) define as "corruption as "the misuse of public power for private benefit and it usually arises in the interactions between the public and private sector" (p. 93). On the other hand, Dutta \& Sobel (2016) contend that most studies focus on the instances of corruption which appear when public officials have to perform a service or to enforce legislation in dealings either with the citizens or with private entities. Notwithstanding, corruption can also appear in business-to-business relations whenever a party offers 'incentives' to another in return for an action that goes against the prescribed role for that party (Halter, Coutinho de Arruda \& Halter, 2009). In general, private sector forms of corruption have been less studied because it is believed that market competitions and penalties for anticompetitive behaviour reduce the incentives to engage in this type of behaviour, and that other forms of corruption have a larger and more 
significant impact on the development of the economy and the stability of the political system (Argandona, 2003). Thus, it is important to be aware of the generality of corruption, although public corruption is the prevalent form of corruption across the globe (Judge et al., 2011; Ortiz-Ospina \& Roser, 2016).

Worth mentioning that there are two highly different opinions on the impact of corruption on the development of entrepreneurship and economy as a whole. On the one hand, there is the 'grease the wheels' perspective which holds that corruption is beneficial for the development of new businesses, especially when corruption can be used via bribes in order to influence the legislative process to help increase the efficiency of governmental regulations and in order to alleviate the barriers for market entry and business development. (Spiller, 1990; Dreher and Gassebner, 2013; Dutta \& Sobel, 2016). On the other hand, there is the 'corruption is harmful' perspective which holds that lower corruption favours better protection of property rights, strong public institutions that are able to design regulations that foster economic development, and better development of larger businesses capitalizing on favourable business environment. The aforementioned is monitored through data from the Global Entrepreneurship Monitor (Estrin et al., 2013; Dutta and Sobel, 2016).

The World Bank (2020) affirms that "Corruption erodes trust in government and undermines the social contract. This is cause for concern across the globe, but particularly in contexts of fragility and violence, as corruption fuels and perpetuates the inequalities and discontent that lead to fragility, violent extremism, and conflict" (para 5). Lebanon is no exception. Indeed, Lebanon is a country with a weak political system and a very frail economic system where instances of corruption are generally considered the norm (Kadi, 2019).

\subsection{Corruption in Lebanon}

Corruption is considered an endemic problem in Lebanon. Currently, according to Transparency International (2021a), Lebanon is ranked 149 out of 180 countries based on the Corruption Perceptions Index of 2020, after having received a score of 25 out of a maximum of 100. In fact, the same organization's report (Transparency International, 2021b) asserts that, "with a score of 25, Lebanon significantly declined on the CPI, dropping five points since 2012. Despite popular protests, no major investigations have been conducted, nor have any public officials been put on trial" (para 14).

The high level of corruption has had a negative impact on the economic development of the country (Ghoneim \& Ezzat, 2016), has increased the level of citizen distrust in the public sector leading to a general reluctance to follow norms and regulations (Alijla, 2016) and has been cited as one of the major drivers of emigration especially among younger Lebanese (Pearlman, 2013; Dibeh, Fakih \& Marrouch, 2017; 2018). The wide spread of various forms of corruption including bribery, nepotism, favouritism, and patronage is a result of a weak legislative framework, numerous conflicts among the political class, a lack of anti-corruption public institutions, as well as a general low level of awareness of the detrimental effects of corruption (The Lebanese Transparency Association, n.d., Ali, 2021). Worth mentioning that corruption is also part of the power division in Lebanon as Salloukh (2019) argues that the Taef agreement (the basis for the ending of the civil war and the return to political normalcy in Lebanon) more than 30 years ago "created a more balanced consociational power-sharing arrangement; however, this led to a "bigger, more clientelist, more corrupt public sector". Furthermore, Ahmad et al. (2020), believe that the "poor governance and performance of Lebanon's public entities "is the lack of coordinated vision and the sectarian distribution of state funds, as in the case of the Lebanese Council of Development and Reconstruction" (p. 11). Corruption in the public sector affects the business sector as well since most businesses in Lebanon report that they were requested to pay a bribe by a public servant at least once and that failure to comply with these requests usually affects the development of the business (Gan Integrity, 2020; Ali, 2021). In fact, the UN (2001) reports that "over $43 \%$ of foreign companies in Lebanon "always or very frequently" pay bribes and another $40 \%$ "sometimes" do" (p. 3). Moreover, businesses' corruption usually surface clearly during crisis as is the case of Beirut Port construction after the devastated explosion whereby construction companies, "are accepting short-term concessions to avoid lasting reform, in the hopes of reactivating stagnant patronage networks in the future" (Boswall \& Wood, 2020, para 4). As a result, it is necessary to explore the ways in which Lebanese businesses perceive corruption and the methods which could be used in order to combat corruption in the business sector.

\subsection{Significance of the Study}

Previous studies have explored the issues caused by corruption by using secondary data, which showed that corruption has a negative effect on the development of various economic sectors (Hakimi \& Hamdi, 2017) and that it also affects the decisions of foreign investors (Cuervo-Cazzura, 2006). In addition, Haykal (2017), using mathematical modelling, has shown that corruption has become a social norm in Lebanon which explains why initiatives meant to combat corruption have proven ineffective (Haase, 2018). However, besides a study done on 
the perceptions of business students in regard to corruption (Neal et al., 2015), no other study has investigated the ways in which the actors from the business sector conceptualize corruption, experience its effects, and evaluate potential solutions for dealing with corruption. The present study aims to fill this gap in the literature by focusing on the exploration of the ways in which Lebanese managers and employees understand and evaluate the effects of corruption in the business sector.

In light of this, the present study is focused on Lebanese businesses and aims to assess managers' and employees' perceptions on corruption with the aim to investigate the underlying assumptions, organizational norms and motivations that foster corruption as well as to explore mitigation strategies to reduce corruption in the business sector.

\subsection{Research Questions}

The present study aimed to answer the following research questions:

\section{RQ1: In what ways do perceptions of corruption differ between Lebanese managers and employees?}

The question refers to the differences in perception regarding the underlying assumptions that affect the ways in which managers and employees relate acts of corruption to ethical values. For example, Neal et al. (2015) presents two counter arguments. The first insinuates that acts of corruption may be excused by choosing a utilitarian perspective which emphasizes that consequences are more important than the nature of the actions; while the second suggests that having an ethical perspective based on virtues might be inclined to condemn all forms of corruption irrespective of whether they have desirable or undesirable consequences.

\section{RQ2: What are the costs of corruption from the perspective of Lebanese managers and employees?}

Ghoneim \& Ezzat (2016) clarify herein that the costs of corruption could stem from costs that directly affect the operations of the business (e.g., a rise in operational costs, the lack of qualified personnel etc.) or could result from costs that have an indirect negative effect on the business (e.g., an unstable political system, poor public infrastructure etc.).

RQ3: What is the most effective method of dealing with corruption in the business sector from the perspective of Lebanese managers and employees?

This question seeks to investigate whether there is a significant preference for one type of method dealing with corruption over others and if this preference is influenced by the position held in the business (i.e., manager versus employee). In particular, the question focuses on methods that are internally driven (i.e., methods focused on the actions taken by businesses in order to prevent corruption) versus methods that are externally driven (i.e., methods taken by public authorities in order to deter and punish acts of corruption in the business sector). For example, internally driven methods include instituting organizational zero-tolerance policy on bribery \& corruption, improving compliance using incentives, and including the value chain in organizational anti-corruption programmes, among others (Demming, 2021).

This study is divided as follows: Section one presented an introduction and background of the research followed by the Methodology in section two. Section three shows the results and findings, whereby section four is about the discussion. Section five ends the study with the conclusion and implications of the research.

\section{Methodology}

The present study adopted an exploratory quantitative research methodology based on the positivistic approach to social studies. According to Hejase \& Hejase (2013), "Positivism is when the researcher assumes the role of an objective analyst, is independent, and neither affects nor is affected by the subject of the research" (p. 77). Moreover, the study used a deductive approach in which data was gathered and then used in order to assess theoretical statements about the perceptions of the business sector in regard to corruption.

\subsection{Sampling}

The sampling strategy chosen for the present study was convenience sampling. In fact, the snowballing technique was implemented. The final valid sample for the study consisted of 25 managers from different Lebanese businesses and 25 employees from the same businesses. The researchers contacted as many as possible managers who were either friends or acquaintances and then asked each manager to suggest the name of another manager as well as the name of one of his/her subordinates who would be willing to participate in the study. The target was 100 managers and employees, however the final sample consisted of 50 respondents who were reached with difficulty, making a response rate of 50\%. The researchers took extreme caution in ensuring that the sample was sufficiently heterogeneous in terms of gender and industry in order to increase the validity of the data and avoid any biases which could arise from oversampling certain categories of respondents. Data was 
gathered using a web-based survey designed using Google Forms. Data was collected during the period extending from January $10^{\text {th }}, 2021$ to February $10^{\text {th }}, 2021$.

\subsection{Questionnaire Design}

The survey method was chosen because it allows the collection of data from a large sample of respondents in a shorter amount of time and because it matched the safety requirements for conducting research during the COVID-19 pandemic. The survey contained 10 closed-ended questions as follows: 5 socio-demographic questions (e.g., age, gender, seniority on the current position, industry, position in the business) and 20 statements which were assessed either based on 5-level Likert scale (10 of which were coded: 1 - strongly disagree, 5 - strongly agree; and 5 which were coded 1- Not affected and 5- fully affected) or on multiple choices ( 2 questions) where only one answer was accepted. The validity of the survey was tested by sending the survey to a group of respondents (managers and employees) who were not included in the final sample and were asked to provide feedback on the wording of the questions as well as on their saliency for the study's aims. Based on the feedback received, no modifications were required.

\subsection{Research Ethical Concerns}

Before filling in the survey, each participant received an invitation letter which highlighted the purpose of the study, the ways in which data would be used as well as the rights and responsibilities of the participants. Participants' involvement was entirely voluntarily and their willingness to participate was respected with no strings attached. Furthermore, confidentiality was assured by keeping the participants' identities unknown, no any personal data was, and all responses will be only utilized for academic research purposes.

\subsection{Data Analyses}

Suitable statistical tools were used whereby, Hejase et al. (2012, p. 129) contend that informed objective decisions are based on facts and numbers, real, realistic and timely information. Furthermore, according to Hejase \& Hejase (2013), "descriptive statistics deals with describing a collection of data by condensing the amounts of data into simple representative numerical quantities or plots that can provide a better understanding of the collected data" (p. 272). Consequently, this research used frequencies and percentages depicted in tables and figures. The collected data was analysed using Microsoft Excel.

\section{Findings}

\subsection{Demographics}

The sample was mainly formed of millennial respondents, since the average age for the managers was 35.2 years and that for the employees was 29.6 years. In terms of gender, the managers sample was $36 \%$ females and $64 \%$ males while the employees sample was $48 \%$ females and $52 \%$ males. On the average, the managers had spent 2.4 years in their current position, while the employees spent 3.6 years, which hints that most of the respondents had sufficient time to get accustomed to the organizational norms and practices. The breakdown on the sample based on industry showed that $32 \%$ of the respondents worked in banking, finance \& insurance, $32 \%$ in telecommunications, $16 \%$ in construction, $8 \%$ in education and $12 \%$ in a variety of other industries (tourism, medical, logistics, etc.).

\subsection{Perceptions on Corruption in the Business Environment}

Table 1 shows that the most commonly encountered assumptions regarding corruption among the respondents were those referring to the ethical ambiguity of acts of corruption (3.93 overall average score), the prevalence of corruption in the business sector (3.85 overall average score), and the usefulness of using acts of corruption in order to attain socially desirable goals (3.84 average score). In contrast, the respondents were less inclined to associate corruption with the existence of an evil human nature (2.96 overall average score) or to consider that criticizing the existence of corruption is a sign of a poor understanding of business practices (3.47 overall average score). The analysis also revealed that managers tend to have a more lenient approach when it comes to corruption in comparison to the employees, regarding it as an inherent feature of the business environment (average score of 4.16 versus 3.54) which is not always connected with unethical behaviours (average score of 4 versus 3.86) and would not be as condemned as it is if people would have a better grasp of the functioning of the business environment (average score of 3.68 versus 3.26). In contrast, employees showed more support than managers for the assumption that acts of corruption can be accepted when they contribute to the achievement of a higher purpose (average score of 3.92 versus 3.76 ). 
Table 1. Perceptions regarding corruption among the Lebanese managers and employees

\begin{tabular}{llccc}
\hline No. & Statement & Managers & Employees & Overall \\
\hline $\mathbf{1}$ & $\begin{array}{l}\text { Those who condemn all forms of corruption have no } \\
\text { understanding of the business environment }\end{array}$ & 3.58 & 3.26 & 3.47 \\
\hline $\mathbf{2}$ & $\begin{array}{l}\text { Corruption is an inherent part of human nature which is selfish and } \\
\text { evil. }\end{array}$ & 3.14 & 2.78 & 2.96 \\
\hline $\mathbf{3}$ & Acts of corruption are not always unethical & 4.00 & 3.86 & 3.93 \\
\hline $\mathbf{4}$ & Corruption is a common business practice & 4.16 & 3.54 & 3.85 \\
\hline $\mathbf{5}$ & $\begin{array}{l}\text { Sometimes norms have to be violated in order to achieve a } \\
\text { desirable goal. }\end{array}$ & 3.76 & 3.92 & 3.84 \\
\hline
\end{tabular}

Note: Participants' agreement on statements was based on 5-level Likert scale as follows: Strongly Agree: 5, Agree: 4, Indifferent: 3, Disagree: 2 , and Strongly Disagree: 1.

\subsection{Motivational Factors Which Drive Corruption}

Results from Figure 1 show that the overall agreement among the respondents was that corruption is primarily caused by explicit requests from public officials (30\% of the sample), anti-competitive behaviours from other businesses (24\% of the sample) and high-performance expectations from superiors ( $20 \%$ of the sample). The factors with the least importance were personal gain (12\% of the sample) and unclear legislation (14\% of the sample). The breakdown of the responses based on the position in the organization, revealed certain interesting differences between the perceptions of the managers and those of the employees. On the one hand, managers allocated a greater importance to external factors such as the corruption in the public sector $(40 \%)$ and the anti-competitive practices of other businesses in the same industry (32\%), but saw personal interest (8\%), poor legislation (8\%) and unrealistic performance expectations (12\%) as less important drivers of corruption. On the other hand, employees were of the opinion that an important driver for corruption is generated internally by the high-performance expectations of their superiors $(28 \%)$ which might cause them to seek means to attain their objectives outside the boundaries of the law. In addition, the employees allocated a much lower importance to the corruption in the public sector (20\%) and a higher importance to personal motives (16\%) that might drive people to engage in acts of corruption.

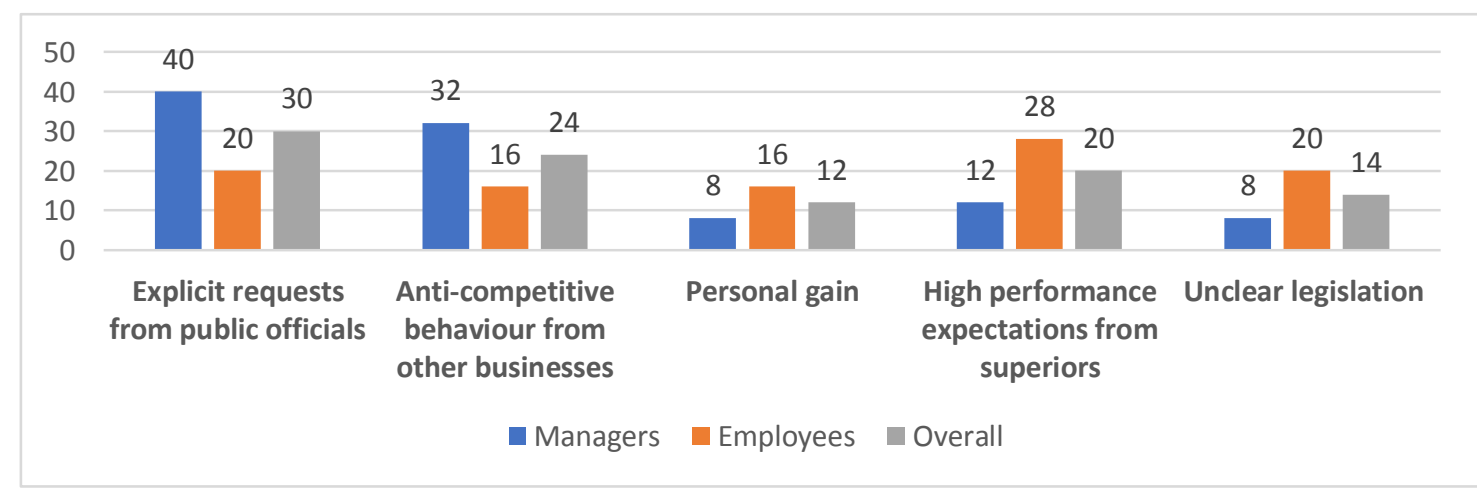

Figure 1. Drivers of corruption in the business environment

\subsection{Organizational Norms and Costs of Corruption in the Business Environment}

The study also explored the ways in which organisational norms enable corruption. As shown in Table 2, there was a general agreement among the respondents that their organizations lacked the necessary managerial control as well as fail to enforce norms that could prevent corruption. The three items with the highest overall scores were related to the fact that managers do not monitor the activities of their subordinates ( 3.71 overall average score), that they often overlook cases of corruption (3.63 overall average score) or to the fact that the employees who engage in acts of corruption are not always punished (3.64 overall average score). In contrast, there was general consideration that managers do not encourage acts of corruption (3.1 overall average score). However, 
the comparison of the responses by managers and employees highlighted certain areas of disagreement. The employees were more likely to consider that the managers are not performing their monitoring function effectively (4.16 average score versus 3.26) and that managers often turn a blind eye to instances of corruption (3.92 average score versus 3.34). In addition, in contrast to the managers, the employees considered that managers sometimes encourage their subordinates to engage in acts of corruption (3.64 average score versus 2.56) and that the employees who engage in these acts are usually not punished (3.74 average score versus 3.54 ). The only item where the managers registered a higher score than the employees referred to the existence of norms in the organizations that punish those who engage in acts of corruption (3.88 versus 3.34).

Table 2. Organizational norms related to corruption

\begin{tabular}{llccc}
\hline No. & Statement & Managers & Employees & Overall \\
\hline $\mathbf{1}$ & $\begin{array}{l}\text { Managers sometimes encourage their subordinates to } \\
\text { engage in acts of corruption }\end{array}$ & 2.56 & 3.64 & 3.10 \\
\hline $\mathbf{2}$ & $\begin{array}{l}\text { Managers often overlook cases of corruption inside the } \\
\text { organization }\end{array}$ & 3.34 & 3.92 & 3.63 \\
\hline $\mathbf{3}$ & $\begin{array}{l}\text { Employees are seldom punished for engaging in acts of } \\
\text { corruption }\end{array}$ & 3.54 & 3.74 & 3.64 \\
\hline $\mathbf{4}$ & $\begin{array}{l}\text { There are no organizational punishments for employees } \\
\text { who engage in acts of corruption }\end{array}$ & 3.88 & 3.34 & 3.61 \\
\hline $\mathbf{5}$ & Managers often do not monitor what their subordinates do & 3.26 & 4.16 & 3.71 \\
\hline
\end{tabular}

Note: Participants' agreement on statements was based on 5-level Likert scale as follows: Strongly Agree: 5, Agree: 4, Indifferent: 3, Disagree: 2, and Strongly Disagree: 1.

Moreover, the study aimed to explore the costs of corruption on the business environment in Lebanon. According to Figure 2, and on an overall scale, the respondents agreed that corruption affects operational costs (40\%) by increasing the cost of doing business and thus hurting the profitability of the business. In addition, the respondents said that corruption is less likely to affect other aspects of the business such as access to a stable political system (18\%), a sound and certain system for public contracting (16\%) and good quality personnel (14\%). According to the respondents, corruption has the least negative effect on access to good quality public infrastructure $(12 \%)$. The analysis of the answers provided by managers and their employees showed a number of differences in opinions. For example, the employees were more inclined to see corruption as a factor which affect operational costs (48\%) and the stability of the political system (24\%), while the managers allocated a higher importance to the negative effects of corruption on the ability to recruit qualified personnel (20\%) and the certainty of the public contracting system (20\%).

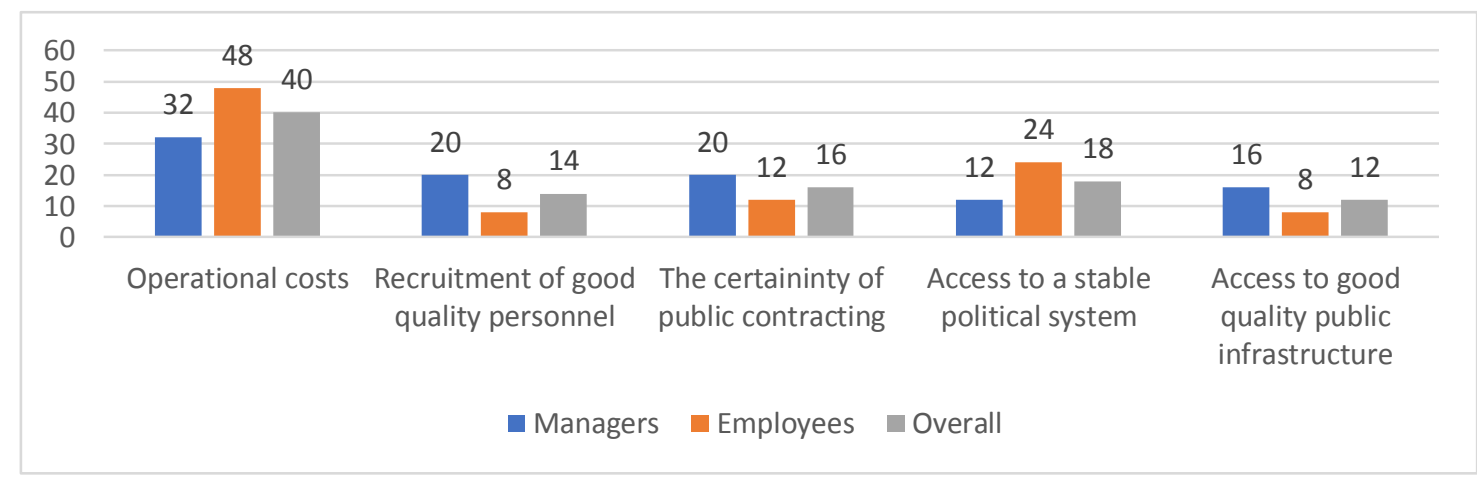

Figure 2. The costs of corruption for businesses in Lebanon

\subsection{Strategies for Dealing With Corruption in the Business Environment}

The respondents were given a range of choices which stemmed from initiatives coming from the public 
authorities to initiatives coming from inside the business environment. Table 3 shows that the respondents were split between the preference for a stricter application on the current laws by public authorities $(30 \%)$ and the establishment of corporate codes of ethics based on international standards (34\%). The other two choices were preferred by only a small number of respondents, i.e., the establishment of a national system to monitor and punish acts of corruption and the establishment of industry associations entitled to monitor and punish acts of corruption were each chosen by $18 \%$. However, the comparison between the opinions of the managers and those of the employees revealed significant differences. On the one hand, the employees saw the application of current laws of public authorities (40\%) as the most effective method of dealing with corruption in the business sector, while, on the other hand, the managers were of the opinion that the most effective strategy is to allow businesses to establish their own codes of conduct based on international best practices $(40 \%)$. However, it is also clear that the employees preferred the establishment of internal codes of conduct (28\%) above other strategies such as establishing a national anti-corruption system $(16 \%)$ or allowing industry associations to monitor the behaviour of their members $(16 \%)$.

Table 3. Strategies for dealing with corruption in the Lebanese business environment

\begin{tabular}{llccc}
\hline No. & Statement & Managers & Employees & Overall \\
\hline $\mathbf{1}$ & $\begin{array}{l}\text { The establishment of industry associations entitled to } \\
\text { monitor and punish acts of corruption }\end{array}$ & 20 & 16 & 18 \\
\hline $\mathbf{2}$ & $\begin{array}{l}\text { The establishment of a national system to monitor and } \\
\text { punish acts of corruption }\end{array}$ & 20 & 16 & 18 \\
\hline $\mathbf{3}$ & $\begin{array}{l}\text { The development of corporate codes of ethics based on } \\
\text { international standards }\end{array}$ & 40 & 28 & 34 \\
\hline $\mathbf{4}$ & A stricter application of current laws by public authorities & 20 & 40 & 30 \\
\hline & Total & $100 \%$ & $100 \%$ & $100 \%$ \\
\hline
\end{tabular}

Note: Multiple Choice Question with one response only. Numbers recorded in \%.

Overall, the results show that there are significant differences between the ways in which managers and employees understand the motivations and effects of corruption in the Lebanese business environment, as well as on the strategies that would be most effective in dealing with the spread of corruption among Lebanese businesses. The most significant results will be discussed in the following section which compares the findings of the present study with similar studies both from Lebanon and other countries.

\section{Discussion}

The study aimed to explore the different perceptions Lebanese managers and employees had toward corruption. The resultant different arguments in this research which were invoked to excuse acts of corruption fit Haykal's (2017) and Bassil's (2017) arguments that corruption has become so widespread in Lebanon that it has transformed into a social norm which explains why corrupt behaviours are tolerated. In fact, Haykal (2017) proved that when people adopt a rational perspective when dealing with corruption, they base the morality of their actions on what the expected behaviours of others, thus leading them to accept corruption as a viable way of doing business as long as a sufficiently large number of other businesses are expected to adopt a similar behaviour. In addition, the study found that managers were more inclined than their employees to view corruption as a common business practice which could be explained by the fact that, due to their position in the organization, they are more likely to be exposed to acts of corruption (Anand et al., 2005). In contrast, the employees were more inclined to appeal to higher purposes in order to explain why corruption could be considered acceptable, a perspective which was also found among the Lebanese students included in the study performed by Neal et al. (2015). The application of utilitarianism as a means to explain why corruption should be tolerated is prevalent in countries where corruption is rampant (Ashford \& Anand, 2003), which is the case of Lebanon. However, the respondents were also reluctant in associating corruption with the idea that human nature is inherently evil as found in the study done by Kluckhohn and Strodtbeck (1961). Actually, the major finding of the current study is that corruption has become so ingrained in the social fabric of the Lebanese society that it is no longer associated with questions of morals, but with questions of what is the most rational choice which can be made in a context where corruption is a commonly encountered practice. The aforementioned also explains why most recent attempts at curtailing corruption have proven to be ineffective (Haase, 2018), since they were 
unable to establish new social norms that would make sense for the rational economic actor who performs a cost-benefit analysis and concludes that corruption is a viable mean of attaining his/her goals. Thus, it could be argued that both the managers and the employees employ selective social comparisons (Anand et al., 2005) when engaging in acts of corruption in order to establish a basis for maintaining the status quo.

In terms of drivers of corruption, the study found that the two main motivation factors were the requests of public officials for bribes, favours and other type of incentives in order to perform their duties and the anti-competitive behaviours of other businesses. The high score obtained by corrupt behaviour of similar businesses is reflective of the discussion in the previous paragraph where it was established that corruption is seen as an expected business practice, which makes it necessary to use corrupt practices in order to remain competitive, since it is known that corruption affects the working of normal market competition (Hakimi \& Hamdi, 2017). Indeed, Transparency International (2019), in its survey to citizens in six countries including Lebanon, found that $37 \%$ of Lebanese citizens ranked business executive $4^{\text {th }}$ as corrupted. This ties in with the findings of previous studies regarding the prevalence of bribes in the public sector. For example, Kairouz et al. (2016) found that $95 \%$ of the people surveyed considered public servants to be corrupt and that approximately $70 \%$ had to pay a bribe at least once to facilitate access to public services. In addition, Haase (2018) found that most businesses have to pay bribes in order to obtain certain permits or authorization as well as to avoid being fined for issues that are either invented or the result of unclear legislation. Notwithstanding, Transparency International (2019) also found that Lebanon has the highest overall bribery rate of $41 \%$ and 'wasta' rates of $54 \%$.

However, the most interesting finding of the study relates to the perceptions of the employees who allocated a large importance to the high-performance expectations of their superiors. Participant employees expressed their opinion that corruption is caused by the fact that their superiors set performance objectives which are unattainable through legal means. This is an interesting aspect since most studies until now have regarded corruption as a result of either systemic issues or personal motives, whilst overlooking the fact that organizational culture might foster corruption by motivating employees to adopt corrupt behaviours in order to survive (Anand et al., 2005). The fact that there is a large discrepancy between the views of the managers and the employees in regard to the contribution of high-performance expectations to the proliferation of corruption, points towards the fact that Lebanese managers might unknowingly contribute to the creation of an organizational culture with tolerates corruption.

The study also found that there is a difference in perception regarding the organizational norms that are supposed to combat corruption in Lebanese businesses. In line with the aforementioned findings, the employees considered that the managers were not performing their control function effectively, and that they often disregarded acts of corruption, if not directly encouraging their subordinates to behave in a corrupt manner. Researchers like Craft (2013) and O'Fallon \& Butterfield (2005) have shown that an ethical organizational culture is able to reduce the instances of corrupt behaviour especially when managers are able to set a moral example to their employees. However, little is known about the ways in which managers can actually encourage corruption as found in the present study, especially since most studies do not distinguish between organizational corruption and counterproductive corruption (Pinto et al., 2008). Thus, it might be the case that Lebanese managers foster the adoption of corrupt behaviours that are effective and efficient means of attaining organizational goals, and seek to punish or discourage acts of corruption that are detrimental to the organization such as those inspired by personal gain. However, this line of investigation goes beyond the scope of the present paper which can only establish that the laxity of the managers in what regards ethical aspects as well as their focus on objectives act as motivators for employees to engage in acts of corruption. In fact the managers' laxity towards ethical aspects behaviour goes against the recommendation of the World Bank (1997) which states, "In the long run, controlling corruption in the private sector may require improvements in business culture and ethics" (para 10). In addition, UNDOC (2019), recommends anticorruption practices for stakeholders of the private sector (such as: employees, customers, shareholders, business partners and civil society) the following "establishment of an effective ethics and compliance programme, which goes beyond mere compliance and aims to foster a culture of integrity, should include internal, external and collective measures" (para 1).

As it was to be expected, the study found that the respondents evaluated the negative effects of corruption by focusing on the direct effects to business activities. As a result, the increase in operational cost as a result of the fact that bribes and other form of grease payments had to be made was cited as the most important effect of corruption on the business sector (Myint, 2000). However, the study also found that employees failed to understand the way in which even petty corruption contributes to the poor quality of public services and the stability of the political system, effects which have been shown to have significant effects on the ability of 
Lebanese businesses to survive and thrive (Alijla, 2016; Ghoneim \& Ezzat, 2016). In contrast, managers had a much wider view of the negative effects of corruption, showing an awareness of the fact that corruption affects the ability to recruit qualified personnel, the certainty of public contracting, the quality of public infrastructure and the stability of the political system. However, although managers are aware of these negative consequences, they also appear to be reluctant to impose any organizational norms that would curtail corruption, probably as a result of a reasoning that equates acting ethically and lawful with the loss of competitiveness.

Finally, the study sought to identify the respondents' opinions regarding the strategies to deal with corruption in the Lebanese business environment. The most significant finding was that the respondents considered that there was no need for a modification in legislation in order to deal with corruption. Instead, they focused on the idea that the legislative system is good, but is applied in an ineffective manner. The aforementioned is actually contrary to the study by Transparency International (2019) which reported that $27 \%$ of the Lebanese respondents ranked as $9^{\text {th }}$ the corruption among Judges and magistrates in the Lebanese legal system. Moreover, along the same line, the finding abovementioned goes counter to the results of other studies which have established that the legislative system in Lebanon is filled with lacunae, conflicting norms, and ambiguous requirements which actually impedes the application of the law (Haase, 2018). In addition, the study found that the respondents viewed the establishment of ethical codes of conduct as an effective means to combat corruption. As previously mentioned, there is a general agreement in the literature that establishing ethical organizational norms reduces the number of acts of corruption (Craft, 2013), but there is a problem with these studies since they were performed in Western countries where corruption is not an endemic issue as in Lebanon. As a result, allowing Lebanese businesses to police themselves could prove to be ineffective since, in line with Haykal's (2017) and Bassil's (2017) and the present study's findings, corruption has become a social norm and a type of behaviour that is not only tolerated but seen as an acceptable way of attaining one's goals. Thus, even if Lebanese businesses were to establish clear codes of conduct which punish corruption, these codes could prove to be ineffective in dealing with corruption, since, as it was previously discussed, Lebanese managers are often reluctant to monitor and punish the unethical behaviour of their employees.

\section{Conclusion}

Corruption is currently one of the major problems faced by Lebanon (BBC, 2020) since it is regarded as the most important factor which determines the standard of living and the satisfaction of the citizens with the public system. Although corruption is seen as an endemic problem of the Lebanese public administration (Baker \& Perry, 2020), its effects are felt by all social actors, including the business sector. The present study showed that the prevalence of corruption has led to the establishment of social norms which tolerate (Kadi, 2019) and even consider corruption as a viable business practice in the Lebanese business environment. In addition, Adra (2006; quoted by Farida \& Ahmadi-Esfahan, 2008) claims that "corruption became an enduring fact of life, that is, of social norms and practices" (p. 3). Moreover, the study showed that the organizational cultures support corrupt practices which are either required in order to remain competitive or to be able to achieve high performance goals, contrary to the latest recommendations by UNDOC (2019). However, the limitation in the current study regarding the small sample of Lebanese managers and employees leads to the fact that the results cannot be generalized to the entire Lebanese business sector. However, since findings are exploratory and significant, these act as an eye opener to other researchers and decision makers. The recommendation is to carry out future studies to confirm the findings of the present study by using a larger and more representative sample of the population of the Lebanese business sector. Moreover, it would be useful for future studies to employ qualitative research data gathering methods in order to explore the type of corruption that is overlooked or not punished by Lebanese managers (i.e., organizational corruption or counterproductive corruption). Furthermore, explore the assumptions that are currently being used in order to explain the adoption of a viewpoint which either tolerates or supports the adoption of corrupt behaviours in the business environment. Overall, the paper asserts that corruption has become so entrenched in the everyday practices of all Lebanese social actors that it is difficult to design strategies to combat corruption. In fact, this fits the description of "the loss of state legitimacy; a state considered to be corrupt, negligent, and showing little concern for protecting public interests or soundly managing its finances" (Maïla, 2020). Hence, reform strategies are not possible without having a complete understanding on the ways in which social actors use corruption as a means to attain their goals. Thus, further studies on this topic are necessary in order to provide a sound basis for the development of both organisational and public policies aimed at reducing corruption in the business sector.

\section{References}

Ahmad, A., McCulloch, N., Al-Masri, M., \& Ayoub, M. (2020, December). From dysfunctional to functional corruption: The politics of reform in Lebanon's electricity sector. Anti-Corruption Evidence (ACE) 
Research Consortium, Working Paper No. 30. Retrieved June 21, 2021, from https://www.aub.edu.lb/ifi/Documents/publications/working_papers/2020-2021/20201218_from_dysfunctio nal_to_functional_corruption_working_paper.pdf

Ahmad, E., Ullah, M. A., \& Arfeen, M. I. (2012). Does Corruption Affect Economic Growth?. Latin American Journal of Economics, 49(2), 277-305. https://doi.org/1O.7764/LAJE.49.2.277

Ali, M. (2021, February 23). Poverty and Corruption in Lebanon. The Borgen Project. Retrieved June 21, 2021, from https://borgenproject.org/poverty-and-corruption-in-lebanon/

Alijla, A. (2016). Between inequality and sectarianism: who destroys generalized trust? The case of Lebanon. International Social Science Journal, 66(220), 177-195.

Anand, V., Ashforth, B. E., \& Joshi, M. (2005). Business as usual: The acceptance and perpetuation of corruption in organizations. Academy of Management Executive, 19(4), 9-23.

Argandona, A. (2003). Private-to-private corruption. Working Paper No. 531. IESE Business School, University of Navarra, Spain. Retrieved May 21, 2021, from https://core.ac.uk/download/pdf/6536429.pdf

Ashforth, B. E., \& Anand, V. (2003). The normalization of corruption in organizations. Research in Organizational Behavior, 25, 1-52.

Baker, L., \& Perry, T. (2020). Explainer: Why is Lebanon in an economic and political mess?. Reuters. $\begin{array}{llll}\text { Retrieved June } & 17, & 2021, & \text { from }\end{array}$ https://www.reuters.com/article/us-lebanon-protests-causes-explainer-idUSKBN1XG260

Bassil, R. B. (2017). Corruption and wasta in Lebanon. (Master of Arts), Department of Political Studies and Public Administration, American University of Beirut. Retrieved from http://hdl.handle.net/10938/21408

BBC. (2020, August 5). Lebanon: Why the country is in crisis. Retrieved June 17, 2021, from https://www.bbc.com/news/world-middle-east-53390108

Boswall, J., \& Wood, D. (2020, December 11). Lebanon's Concrete Cartel: How business interests prevent Lebanon from rebuilding its infrastructure, government, and economy. Foreign Policy. Retrieved June 21, 2021 , from https://foreignpolicy.com/2020/12/11/business-cartels-concrete-lebanon-infrastructure-economy-governance/

Craft, J. L. (2013). A review of the empirical ethical decision-making literature: 2004-2011. Journal of Business Ethics, 117(2), 221-259.

Cuervo-Cazurra, A. (2006). Who cares about corruption?. Journal of International Business Studies, 37, 807-822.

Demming, A. (2021). Eliminate Corruption in Your Company with 6 Steps. United Nations Global Compact. $\begin{array}{llll}\text { Retrieved June 25, 2021, from } & \text { Julions }\end{array}$ https://www.unglobalcompact.org/take-action/action/anti-corruption-in-business

Dibeh, G., Fakih, A., \& Marrouch, W. (2017, January). Decision to Emigrate Amongst the Youth in Lebanon. IZA - Institute of Labor Economics, IZA DP No. 10493. Retrieved June 17, 2021, from http://ftp.iza.org/dp10493.pdf

Dibeh, G., Fakih, A., \& Marrouch, W. (2018). Decision to emigrate amongst the youth in Lebanon. International Migration, 56(1), 5-22.

Dreher, A., \& Gassebner, M. (2013). Greasing the wheels? The impact of regulations and corruption on firm entry. Public Choice, 155(3), 413-432.

Dutta, N., \& Sobel, R. (2016). Does corruption ever help entrepreneurship? Small Business Economics, 47(1), 179-199.

Estrin, S., Korosteleva, J., \& Mickiewicz, T. (2013). Which institutions encourage entrepreneurial growth aspirations?. Journal of Business Venturing, 28(4), 564-580.

Farida, M., \& Ahmadi-Esfahan, F. Z. (2008). Corruption and economic growth in Lebanon. Australian Agricultural and Resource Economics Society, 52 ${ }^{\text {nd }}$ Annual Conference, February 5-8, 2008, Canberra, Australia. Retrieved from https://core.ac.uk/download/pdf/6239186.pdf

Gan Integrity. (2020). Lebanon corruption report. Retrieved June 1, 2021, from https://www.ganintegrity.com/portal/country-profiles/lebanon 
Ghoneim, A. F., \& Ezzat, A. M. (2016). Growth and corruption in Arab countries: What type of relationship connects them?. Journal of Economics and International Finance, 8(5), 44-55.

Haase, T. W. (2018). A challenging state of affairs: Public administration in the Republic of Lebanon. International Journal of Public Administration, 41(10), 792-806.

Hakimi, A., \& Hamdi, H. (2017). Does corruption limit FDI and economic growth? Evidence from MENA countries. International Journal of Emerging Markets, 12(3), 550-571.

Halter, M. V., Coutinho de Arruda, M. C., \& Halter, R. B. (2009). Transparency to reduce corruption?. Journal of Business Ethics, 84, 373-385.

Haykal, S. H. (2017). Social norms and conditional corruption: The case of Lebanon. European Scientific Journal, 13(10), 220-231.

Hejase, H. J., Hejase, A. J., \& Hejase, H. A. N. J. (2012). Quantitative methods for decision makers: Management approach. Beirut, Lebanon: Dar Sader Publishers.

Hejase, A. J., \& Hejase, H. J. (2013). Research methods: A practical approach for business students (2nd ed.). Philadelphia, PA, USA: Masadir Inc.

Judge, W. Q., McNatt, D. B., \& Xu, W. (2011). The antecedents and effects of national corruption: A meta-analysis. Journal of World Business, 46(1), 93-103.

Kadi, S. (2019). Lebanon's uphill battle against corruption. Retrieved June 1, 2021, from https://thearabweekly.com/lebanons-uphill-battle-against-corruption

Kairouz, A., Hokayem, J. E., \& Hage, U. E. (2016). Sustainability of public management in developing countries: The case of Lebanon. Procedia - Social and Behavioral Sciences, 221, 378-387.

Kluckhohn, F., \& Strodtbeck, F. L. (1961). Variation in value orientation. New York: Row, Peterson and Company.

Maïla, J. (2020, December). Head-to-Head with Corruption: The Lebanese Challenge. [Edited Translation from French]. Democracy Reporting International - Lebanon Office. Retrieved June 17, 2021, from https://democracy-reporting.org/wp-content/uploads/2021/01/Anti-Corruption-Paper_24022021_english_on line-1.pdf

Maxwell, D., Walker, P., Church, C., Harvey, P., Savage, K., Bailey, S., ... Ahlendorf, M.-L. (2008). Preventing Corruption in Humanitarian Assistance: Final Research Report. Transparency International. Retrieved June 12 , 2021, from https://www.transparency.org/files/content/pressrelease/Humanitarian_Assistance_Report.pdf

Mezoui, O. (2021, 26 February). The Pandemic showed us Corruption is a Global Problem. What Next?. Global Policy. Retrieved June 16, 2021, from https://www.globalpolicyjournal.com/blog/26/02/2021/pandemic-showed-us-corruption-global-problem-wh at-next

Myint, U. (2000). Corruption: Causes, Consequences and Cures. Asia-Pacific Development Journal, 7(2), 33-58. Retrieved June 18, 20921, from https://www.unescap.org/sites/default/files/apdj-7-2-2-Myint.pdf

Neal, M., Finlay, J., Karkoulian, S., Catana, D., \& Pellegrino, R. (2015). How business students view corruption, and why this should concern us: Insights from Lebanon, Romania and the United States. Tertiary Education and Management, 21(2), 140-159.

O'Fallon, M. J., \& Butterfield, K. D. (2005). A review of the empirical ethical decision making literature: 1996-2003. Journal of Business Ethics, 59(4), 375-413.

Ortiz-Ospina, E., \& Roser, M. (2016). Corruption. OurWorldInData.org. Retrieved June 14, 2021, from https://ourworldindata.org/corruption

Pearlman, W. (2013). Emigration and the Resilience of Politics in Lebanon. The Arab Studies Journal, 21(1), 191-213. Retrieved June 20, 2021, from http://www.jstor.org/stable/41968273

Pinto, J., Leana, C., \& Pil, F. K. (2008). Corrupt organizations or organizations of corrupt individuals? Two types of organization-level corruption. Academy of Management Review, 33(3), 685-709.

Salloukh, B. F. (2019). Taif and the Lebanese State: The Political Economy of a Very Sectarian Public Sector. Nationalism and Ethnic Politics 25(1), 43-60. https://doi.org/10.1080/13537113.2019.1565177 
Spiller, P. T. (1990). Politicians, interest groups, and regulators: A multiple-principals agency theory of regulation, or 'Let them be bribed'. Journal of Law and Economics, 33(1), 65-101.

Šumah, Š. (2018, February 21). Corruption, Causes and Consequences, Trade and Global Market. In Vito Bobek (Ed.) Trade and Global Market, (Chapter 5). IntechOpen, https://doi.org/10.5772/intechopen.72953

Svensson, J. (2005). Eight questions about corruption. Journal of Economic Perspectives, 19(3), 19-42.

The Lebanese Transparency Association (n.d.). Corruption in Lebanon. Retrieved from http://www.transparency-lebanon.org/En/Corruption/16

The World Bank. (1997, September). Poverty Reduction and Economic Management: Helping Countries Combat Corruption: The Role of the World Bank. Retrieved June 18, 2021, from http://www1.worldbank.org/publicsector/anticorrupt/corruptn/cor02.htm

The World Bank (2020, December 14). Combating Corruption. Retrieved June 16, 2021, from https://www.worldbank.org/en/topic/governance/brief/anti-corruption

Transparency International. (2019, December 11). What people think: Corruption in The Middle East and North Africa. Retrieved June 16, 2021, from https://www.transparency.org/en/news/what-people-think-corruption-in-the-middle-east-north-africa

Transparency International. (2021a, January 28). Corruption Perceptions Index 2020: Lebanon. Retrieved June 16, 2021, from https://www.transparency.org/en/cpi/2020/index/lbn

Transparency International. (2021b). CPI 2020: Middle East and North Africa. Retrieved June 16, 2021, from https://www.transparency.org/en/news/cpi-2020-middle-east-north-africa

UN (2001). Corruption Assessment Report on Lebanon. United Nations Center for International Crime Prevention 123, Washington DC.

United Nations Office on Drugs and Crime - UNODC. (2019, December). Preventing Private Sector Corruption. The Doha Declaration: Promoting a Culture of Lawfulness. Retrieved June 18, 2021, from https://www.unodc.org/e4j/en/anti-corruption/module-5/key-issues/preventing-private-sector-corruption.ht $\mathrm{ml}$

Wei, S-J. (1998). Corruption in Economic Development: Beneficial Grease, Minor Annoyance, or Major Obstacle?. Proceedings of the Workshop on Integrity in Governance in Asia. The United Nations Development Program and the Transparency International Thailand Chapter, June 29-July 1, 1998. Bangkok, Thailand. Retrieved June 12, 2021, from https://documents1.worldbank.org/curated/en/175291468765621959/129529322_20041117144615/addition al/multi-page.pdf

\section{Copyrights}

Copyright for this article is retained by the author(s), with first publication rights granted to the journal.

This is an open-access article distributed under the terms and conditions of the Creative Commons Attribution license (http://creativecommons.org/licenses/by/4.0/). 